\title{
DEFLECTION SHOOTING IN THE SA AIR FORCE AND SA ARTILLERY 1943-1945
}

\author{
Cdr W.M. Bisset \\ SA Naval Museum, Simon's Town
}

\begin{abstract}
Deflection or clay pigeon shooting for air gunners in the South African Air Force (SAAF) and the Royal Air Force (RAF) in South Africa, commenced on 12 April 1943.
\end{abstract}

A precis for clay pigeon instructors contains the following definition:

"The object of clay pigeon shooting is to teach you how and where to aim to hit a moving target. The knowledge gained will be of the greatest value later on when it comes to handling machine-guns in the air. There is, of course only one place to aim at; that is where the target will be when the bullet arrives".

The officer selected to introduce clay pigeon shooting in the SAAF and ensure its success was Major Jack Wright of the General Service Corps. Cedric Cecil Vernon Wright was one of the sons of $\mathrm{Dr}$ Claude Wright of Wynberg, Cape and was born on 27 May 1899 in Surrey, England. He was educated at Rondebosch Boys' High School and the Royal Military Academy, Sandhurst. He was commissioned on 21 December, 1917 and served in the Indian Army during the Great War and for some years thereafter. ${ }^{1}$

On his return to South Africa he became a company director and joined the Cape Gun Club, a clay pigeon shooting club, whose members included Advocate Oswald Pirow (Minister of Defence 19331939), Major the Hon Piet van der Byl and Captain Charles Struben.

On 5 June 1939 he joined the General Service Corps. He was promoted to the rank of captain on 16 September 1939 and to the rank of major on 18 May 1940. He held the following appointments : Staff Officer to Director-General of Reserves, Military Secretary to the Minister of Defence, Secre- tary of War Supplies Committee, Advisory Member of Defence Advisory Committee, Secretary of the War Committee, Secretary of the Services Manpower Committee and Military Secretary to the Deputy Prime Minister (Colonel the Hon Deneys Reitz, MP who was his brother-in-law). ${ }^{2}$

Until February 1943 Major Wright worked closely with those at the hub of South Africa's war effort.

Acting on the joint authority of the Director of Training (Air Vice-Marshal M.B. Frew), the AdjutantGeneral and the Director-General of the Air Force, Major Wright relinquished his post with the Deputy Prime Minister, Colonel Reitz, who had been appointed South African High Commissioner in London, and reported for duty at Air Force Headquarters in February 1943 to introduce and stimulate clay pigeon shooting to comply with the requirements of the Air Ministry syllabus. ${ }^{3}$

After holding a discussion with Wing Commander Coulson it was decided to introduce clay pigeon shooting in the air schools of 25 Group at Port Elizabeth.

The immediate requirements for 25 Group were eighty 12 bore shotguns, 24 clay pigeon traps, 16 clay pigeon springs and 8 skeet ranges. Trained instructors were urgently needed and it was decided that courses should be held at 66 Air School at Young's Field. All the clay pigeon instructors were experienced air gunner instructors. Material for a skeet range had been made available by the Cape Gun Club and Major Wright supervised its erection which was completed within a week.

Major Wright then returned to Port Elizabeth where his press and radio appeals resulted in about fourteen shotguns being donated to the SAAF. Although these were less than he had hoped to obtain they 


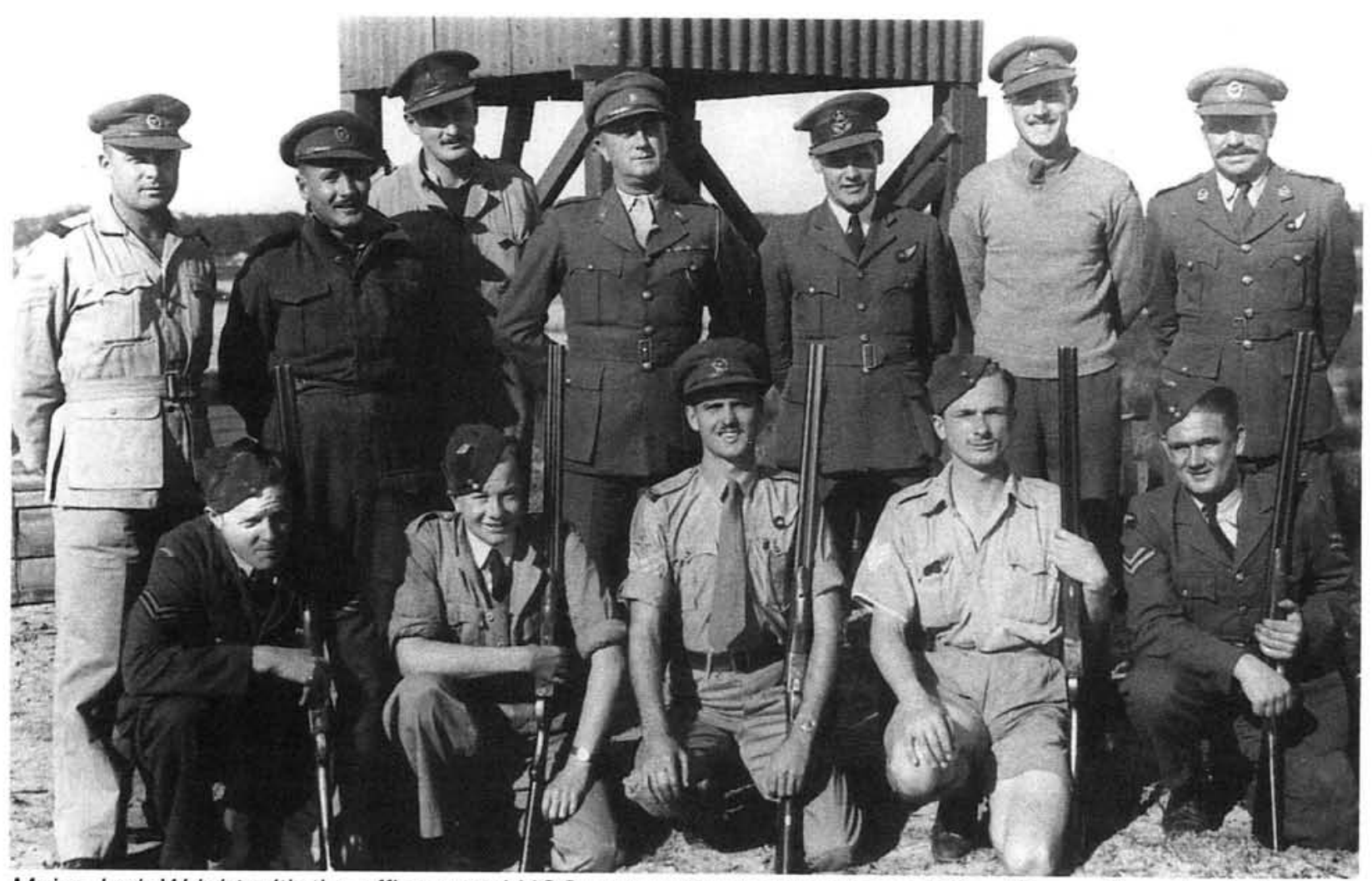

Major Jack Wright with the officers and NCOs who attended the Second Clay Pigeon Shooting Instructors' Course at 66 Air School, Young's Field from 5 to 14 July, 1943. (With permission Mrs K Taylor)

were sufficient to commence the first course. Privately owned clay pigeon traps were also donated to the SAAF.

Attempts to obtain shotguns, confiscated from UDF personnel returning from active service in Ethiopia, from the Customs Department in Durban were unsuccessful.

After the first clay pigeon instructors' course, which was held from 12 - 19 April 1943 at 66 Air School, Major Wright visited all schools and sites chosen for clay pigeon ranges in conjunction with their armament officers. Where the safety zones were inadequate, he negotiated with municipalities and land owners for the use of suitable land on a nominal basis.

Obstructive red tape was soon to threaten the new training scheme. Major Wright's attempts to have a grant of $£ 50$ allocated to each school which would have made it possible to complete the trap houses within a few days was "disallowed and the matter reverted to one of the inter-departmental machinery".

An attempt to utilise funds allocated to air schools for synthetic training failed because Station Commanding Officers were reluctant to define synthetic and actual training and accounting officers would not approve the expenditure.

With the approval of the Air Officer Commanding No 25 Group, Major Wright then visited Pretoria to obtain the necessary approval. Whilst there, he also visited the Minister of Railways, who was Chairman of the Authorities Committee, and submitted a request for $£ 1300$ to purchase shotguns. This was approved soon afterwards. Major Wright conducted the Second Clay Pigeon Instructors' Course at Young's Field from 5 - 14 July 1943. The pupils were from the RAF (5), SAAF (4) and Anti-Aircraft Artillery (2).

On Major Wright's return to 25 Group at the end of the course he discovered that the Public Works Department had authorised the supply of the wrong materials for the ranges. This necessitated another visit to Pretoria to re-submit the correct specifications. During this visit Major Wright interviewed the Director of Anti-Aircraft and arranged to make certain ranges available to anti-aircraft Bofors gun crews.

With the help of Mr Lewis, the Financial Adviser at Impala House and Messrs Joubert and Milan of the Defence Secretariat about sixty shotguns belonging to enemy aliens from South West Africa were requisitioned for deflection-shooting training.

Press advertisements for the purchase of shotguns elicited a good response but the Directorate of War Supplies was unable to effect payment quickly enough and irate sellers reclaimed many of them. After discussions with the Chief Buyer, the Director-General Technical Services authorised Major Wright to value and purchase the shotguns him- 
self. Clay pigeon traps were manufactured locally by Southern Engineering Works at Denver.

Major Wright then requested that Lieutenant Eldred Bisset, a well known clay pigeon shot, be permitted to assist him in his task. This officer was attached to the Air Training Directorate with effect from 1 September 1943. Major Wright and Lieutenant Bisset were later transferred to the SAAF.

Schools in 25 Group had commenced clay pigeon shooting and in a letter to the Director of Air Training dated 16 June 1943 the Air Officer Commanding No 25 Group wrote that "the first quota of pupils at 44 Air School to complete their training with clay pigeon shooting as part of their syllabus have bettered previous drogue shooting scores by $100 \%$. Past records indicate that the average number of hits recorded on drogues is $5 \%$, this now stands at $10 \%$.

"The clay pigeon shooting practice took place just prior to the air to air training which fact would tend to support the supposition that this type of deflection shooting was largely instrumental in bringing about the increase shown".

The pupils attending the third clay pigeon instructors course at Young's Field included men who had recently returned from arduous operational service. Major Wright wrote that "in almost all cases these men were convinced of the benefits to be derived from the teaching of such shooting and the automatic assessment of correct deflection derived therefrom". Lieutenant Bisset assisted with the running of the course and was later introduced to all the air schools of 25 Group.

The shortage of shotguns and deterioration of those on hand necessitated acquiring hammer type guns which were UDF property from the Senior Staff Officer Technical at Cullinan. In addition, a gun hospital was established at 65 Air School but an application for special steel for gun repair work was turned down by the Controller of Steel who implied that scrap metal should be used instead.

Two more clay pigeon instructors' courses were held at 66 Air School by Major Wright and Lieutenant Bisset in quick succession : course 4 from 14 21 June and course 5 from 28 June to 5 July $1944 .{ }^{4}$

On 21 July 1944 Major Wright and Lieutenant Bisset were flown by shuttle service to Cairo and then on to Advanced SAAF Headquarters at Bari in Italy to "investigate the possibilities and desirability of introducing clay pigeon range facilities in the bomber and fighter squadrons of the SAAF in the Middle
East, Mediterranean area and Italy". ${ }^{5}$

When they reported to the Senior Administrative Officer Air it became clear that their presence was "an embarrassment and it was indicated that their hope of successfully fulfilling their mission might prove abortive. It was forcibly indicated that no assistance could be given and no transport facilities made available".

Having obtained permission to act on their own responsibility and initiative the two officers approached the Imperial Forces who permitted them to drive and deliver a Utility lorry to No 14 Vehicle Park outside Rome. They visited 2 Wing SAAF en route and obtained permission to visit 31 and 34 Bomber Squadrons. All the senior officers of the squadrons and wing headquarters were enthusiastic about the introduction of clay pigeon shooting.

Although attempts to obtain UDF, British or American transport in Rome were unsuccessful, they did manage to obtain a lift on a lorry to No 3 Wing and then visited No 21, 24, 12 and 223 Squadrons, where news of plans to introduce clay pigeon shooting was welcomed. They visited the Town Major and AMGOT (Allied Military Government of Occupied Territories) and obtained permission to confiscate shotguns in nearby towns and villages. This request was approved and help was provided by loyal members of the Italian Police. Some shotguns were obtained and these were handed over to the Equipment Officer of No 3 Wing for distribution to their squadrons.

On their return to Rome they learnt that certain arms had been deposited by order of AMGOT in the Central Questero when the city was occupied by the Allies.

Undeterred by discouraging replies and blunt refusals to permit them to inspect the weapons they eventually traced the Regional Commissioner Region IV, Colonel Poletti (AMGOT), who sanctioned the confiscation of up to 50 twelve bore double barrelled shotguns. Clay pigeons and cartridges were still needed.

Another successful visit, this time to 7 Wing, followed. On this occasion Wing Commander Stratford-Tuke of Desert Air Force Headquarters and Squadron Leader Knowles of 36 Air Supply Park agreed to supply two Traps, 750 clay pigeons per month and 500 rounds of 12 bore ammunition per month per squadron. It was agreed that these conservative amounts could be increased progressively as required.

\footnotetext{
Report on Clay Pigeon Instructors' Courses Nos 4 and 5 by Lieutenant E.M.Bisset.

5 'Report on visit to the Middle East, Mediterranean Area and Italy undertaken for the purpose of investigating the possibilities and desirability of introducing clay pigeon range facilities in the Bomber and Fighter Squadrons of the South African Air Force operating in these areas' by Major C.C.V.Wright.
} 
When they returned to Rome arrangements were made for the distribution of the shotguns to all the squadrons visited. They then returned to Egypt where they visited an Air Gunnery School and OTU in the Suez Area. Although limited clay pigeon facilities were available, "in the main the ranges were not in use". Major Wright wrote "those in charge knew little or nothing about skeet shooting or the benefits to be derived therefrom". The exception to this being 13 Air Gunnery School which after demonstration showed "marked keenness to develop its use". No 10 and No 11 Squadrons in the Delta were also visited and arrangements for Clay pigeon facilities were made. Major Wright and Lieutenant Bisset emplaned for the Union on 14 September 1944.
The sixth and final wartime course for clay pigeon shooting instructors was held at 66 Air School from 3 - 16 January 1945 and was conducted by Lieutenant Bisset. ${ }^{6}$

By March 1945 the SAAF Air Schools in the Union were gradually being closed down. Major Wright was released from service on 30 April 1945 and Lieutenant Bisset followed on 24 May 1945.

Major Wright's great love of shooting, his ties with those in high places and his determination to succeed made it possible for him to do so where another officer might have failed. His name is mentioned only in one footnote in one volume of South Africa's official war histories. ${ }^{7}$ 